\title{
Transformation of 'Beurre Bosc' Pear with the rolC Gene
}

\author{
Richard L. Bell, Ralph Scorza, Chinnathambi Srinivasan, and Kevin Webb \\ U.S. Department of Agriculture, Agricultural Research Service, Appalachian Fruit Research Station, 45 \\ Wiltshire Road, Kearneysville, WV 25430-9425
}

AdDitional Index words. Agrobacterium tumefaciens, Agrobacterium rhizogenes, Pyrus communis, Rosaceae, regeneration, growth habit, dwarfing

\begin{abstract}
Beurre Bosc' pear (Pyrus communis L.) was transformed with Agrobacterium tumefaciens (E.F. Smith \& Townsend) Conn strain EHA101 containing the binary vector pGA-GUSGF into which the rolC gene had been inserted. Leaf explants from in vitro shoot tip cultures were wounded, Agrobacterium-inoculated, and cultured on kanamycin selection medium. Regenerating shoots were transferred to proliferation medium without antibiotics. Three clones tested positive for GUS and nptII enzyme activity. Transformation with the rolC gene was confirmed by DNA, RNA, and protein blot analyses. The number of copies of the rolC transgene varied from one to three. Plantlets of the three transgenic clones were acclimated and transferred to the greenhouse. Preliminary observations of phenotype indicate that the rolC gene reduced height, number of nodes, and leaf area of transgenic 'Beurre Bosc'.
\end{abstract}

Genetic transformation using Agrobacterium tumefaciens and engineered binary vectors provides a means of making targeted single trait improvements in clonally propagated crops. Production of pear (Pyrus communis L.) in the United States is dominated by five cultivars; improvements in any of these genotypes could have a great impact on the pear industry. Successful transformation of pear has recently been reported (Merkulov et al., 1998; Mourgues et al., 1996), using marker and reporter genes, but no genes of economic importance.

Production efficiency of deciduous tree fruits has been dramatically improved through the use of dwarfing rootstocks to reduce tree size (Rom and Carlson, 1987; Tukey, 1964). Additional efficiencies have been associated with alterations in growth habit, particularly the introduction of semidwarf or spur-type mutants of apple (Malus $\times$ domestica Borkh.) cultivars. Reduced tree stature in pears has been achieved through the use of quince (Cydonia oblonga L.) as a dwarfing rootstock, and more recently, by several semidwarfing 'Old Home' $x$ ' Farmingdale' clonal rootstocks (Lombard and Westwood, 1987). However, quince rootstocks are not well adapted to most of the major pear production regions of North America, and the degree of size reduction of the 'Old Home' $x$ 'Farmingdale' rootstocks is inferior to quince. Genetically dwarfed scion cultivars have not been commercially introduced.

The rolC gene from Agrobacterium rhizogenes (Riker et al.) Conn, the plant pathogenic bacterium which causes hairy root disease, has been used to transform such species as tobacco (Nilsson et al., 1993; Schmulling et al., 1988; Scorza et al., 1994), potato (Fladung, 1990), tomato (van Altvorst et al., 1992), aspen (Nilsson et al., 1997), and rose (van der Salm, et al., 1992). Growth habit and developmental alterations commonly exhibited by the transformants include increased branching and shorter internodes, traits which result in reduced plant size. Stem fasciation has also been reported (Nilsson et al., 1996). In many of these studies, the rolC gene was

\footnotetext{
Received for publication 7 Jan. 1999. Accepted for publication 25 June 1999. We gratefully acknowledge the technical assistance of Shawn Cain, Jennifer Magaha, Mark Demuth, Tim Artlip, Ann Callahan, and Cassie Bosley. We thank E. Hood for providing EHA101, Y. Dono for the rolC gene, and T. Spena for polyclonal antibody to the rolC protein. Mention of a trademark, proprietary product, or vendor does not constitute a guarantee or warranty of the product by the U.S. Department of Agriculture and does not imply its approval to the exclusion of other products or vendors that also may be suitable. The cost of publishing this paper was defrayed in part by the payment of page charges. Under postal regulations, this paper therefore must be hereby marked advertisement solely to indicate this fact.
}

under the control of the CaMV $35 \mathrm{~S}$ promoter, which has generally produced more extreme effects than the native promoter. The purpose of our research project was to transform pear with the $\mathrm{rolC}$ gene, and to determine the potential of the rolC gene under the control of its native promoter for producing trees of reduced stature and improved production efficiency.

\section{Materials and Methods}

SOURCE OF PEAR LEAF EXPLANTS. Shoot proliferation cultures of 'Beurre Bosc' and 'Bartlett' pear cultivars were established in vitro from cultures (CPYR 1165.001 and CPYR 0038.003, respectively) obtained from the National Plant Germplasm Repository in Corvallis, Ore. Axillary shoots were multiplied in a pear shoot proliferation medium (PSM) containing Murashige and Skoog (1962) basal salts and vitamins (Sigma Chemical Co., St. Louis, Mo.), $30 \mathrm{~g} \cdot \mathrm{L}^{-1}$ sucrose, $5 \mu \mathrm{M}$ benzyl adenine (BA), $0.6 \mu \mathrm{m}$ gibberellic acid $\left(\mathrm{GA}_{3}\right)$, $0.5 \mu \mathrm{M}$ indole butyric acid (IBA), and $6 \mathrm{~g} \cdot \mathrm{L}^{-1}$ noble agar (US Biochemical, Cleveland, Ohio). The $\mathrm{pH}$ of the medium was adjusted to 5.8 before autoclaving. The cultures were grown at $24 \pm 1$ ${ }^{\circ} \mathrm{C}$ with a 16-h photoperiod provided by an equal mixture of warmwhite fluorescent and Vita-lite full spectrum fluorescent (Duro Test Corp., Bergen, N.J.) lamps, with an intensity of 45 to 55 $\mu \mathrm{mol} \cdot \mathrm{m}^{-2} \cdot \mathrm{s}^{-1}$. Young expanding leaves from the actively growing shoot tips were excised from proliferation cultures 4 to 6 weeks after their last transfer, and used for transformation.

Transformation of PEar leaf EXPlants. The disarmed $A$. tumefaciens strain EHA101 containing pGA-GUSGFrolC (Fig. 1) was used for transformation of pear leaves (Scorza et al., 1994). The GUS gene is controlled by the CaMV $35 \mathrm{~S}$ promoter and the $n p t I I$ gene is under the control of the nopaline synthase promoter. The rolC gene (ORF-12 in A. rhizogenes) is controlled by its native promoter. Cultures of EHA101 were grown overnight, pelleted at 2,940 $g_{\mathrm{n}}$, and resuspended in Agrobacterium virulence induction medium consisting of filter sterilized liquid Chevreau and Leblay (CL) basal salts and organics (Chevreau and Leblay, 1993), 10 $\mu \mathrm{M}$ thidiazuron (TDZ), $1 \mu \mathrm{M} \mathrm{IBA}$, and $100 \mu \mathrm{M}$ acetosyringone (AS). The bacterial cultures were incubated for $4 \mathrm{~h}$ on a shaker (100 $\mathrm{rpm})$ at $20{ }^{\circ} \mathrm{C}$ to induce the expression of virulence genes of Agrobacterium (James et al., 1993). After induction, the cultures were diluted to 0.1 and $0.5 \mathrm{OD}$ (at $600 \mathrm{~nm}$ ). An $\mathrm{OD}_{600 \mathrm{~mm}}$ of 0.1 corresponds to $\approx 10^{7} \mathrm{cfu} / \mathrm{mL}$. 


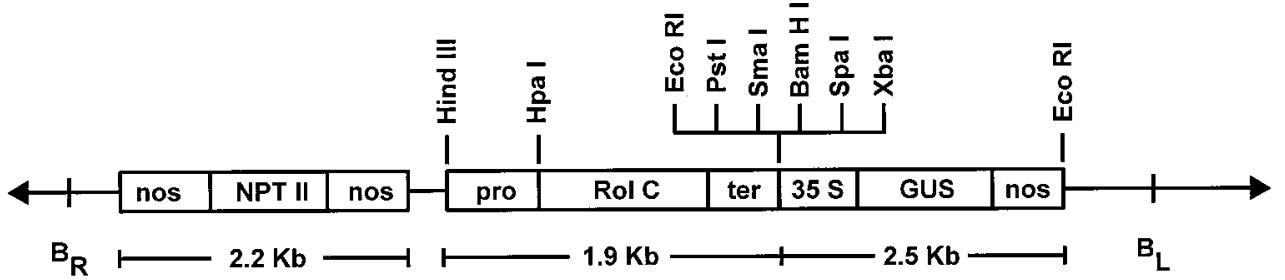

Fig. 1. Schematic partial map of the pGA-GUSGFrolC plasmid containing the NPTII, GUS, and rolC cassettes, and restriction sites.

Sterile scalpel blades dipped in the bacterial suspension $(0.1$ or $\left.0.5 \mathrm{OD}_{600 \mathrm{~nm}}\right)$ were used to make transverse cuts across the midrib of each leaf. The number of cuts per leaf varied from 3 to 10, depending on the size of the leaf. Fifty leaves of each cultivar were inoculated with the $0.1 \mathrm{OD}_{600 \mathrm{~nm}}$ inoculum and 75 leaves of 'Beurre Bosc' were inoculated with the $0.5 \mathrm{OD}_{600 \mathrm{~nm}}$ inoculum. In addition to inoculation of freshly harvested leaves, 50 leaves of each of the two cultivars were wounded and precultured for 1 week in the dark on shoot induction medium (SIM) consisting of CL macronutrients, micronutrients, and organics, plus $10 \mu \mathrm{M}$ TDZ and $1 \mu \mathrm{M}$ IBA, and solidified with $2.5 \mathrm{~g} \cdot \mathrm{L}^{-1}$ Phytagel (Sigma Chemical Co., St. Louis, Mo.) in $100 \times 15 \mathrm{~mm}$ covered petri plates. These leaves were then inoculated by dipping for $20 \mathrm{~min}$ in the bacterial suspension. After inoculation, all leaves were transferred abaxial side down onto cocultivation medium consisting of SIM and $100 \mu \mathrm{M}$ AS. Leaf explants inoculated with $0.5 \mathrm{OD}_{600 \mathrm{~nm}}$ inoculum were cocultivated for $3 \mathrm{~d}$, while leaves inoculated with $0.1 \mathrm{OD}_{600 \mathrm{~nm}}$ inoculum were cocultivated for $4 \mathrm{~d}$. Thirty uninoculated leaves from shoot proliferation cultures of each cultivar were also wounded and cultured on the same cocultivation medium.

The leaf explants were then transferred to antibiotic selection plates containing SIM, $80 \mathrm{mg} \cdot \mathrm{L}^{-1}$ kanamycin, and $300 \mathrm{mg} \cdot \mathrm{L}^{-1}$ timentin (Smith Klein Beecham, Philadelphia, Pa.), and incubated in the dark. After 4 weeks, the cultures were transferred onto shoot expression medium (SEM), which consisted of SIM and 300 $\mathrm{mg} \cdot \mathrm{L}^{-1}$ timentin; IBA and kanamycin were deleted. Cultures were transferred to fresh SEM every 4 weeks, and returned to the dark. When adventitious shoots appeared, they were excised and transferred to fresh SEM, and cultured in the light under the same conditions as that stated for the shoot proliferation cultures. When the shoots had produced two to three leaves, they were transfered to PSM containing $300 \mathrm{mg} \cdot \mathrm{L}^{-1}$ timentin for shoot proliferation. Preliminary experiments indicated that this concentration of timentin did not adversely affect adventitious regeneration. The transformation procedure used in this study differed from that used by Mourgues et al. (1996) and Merkulov et al. (1998) in the vector used, our use of a virulence induction medium containing acetosyringone to resuspend the Agrobacterium culture, our use of timentin instead of ticarcillin and/or cefotaxime to control Agrobacterium after cocultivation, our use of IBA instead of NAA as the auxin used in the shoot induction medium, and our shorter length of time on kanamycin selection medium. Merkulov et al. (1998) used Agrobacterium tumefaciens strain A281.

Histochemical gus assays. Calli, leaves, and stem tissue from the regenerated shoots were assayed for $\beta$-glucuronidase activity following the procedure of Jefferson (1987). GUS-positive clones were multiplied on PSM medium.

Molecular CONFIRMATION OF TRANSFORMation. The GUSpositive clones were subjected to molecular analyses including polymerase chain reaction (PCR) to detect the presence of the gene, and DNA, RNA, and protein blots to confirm the integration and expression of rolC in the pear genome. Pear genomic DNA was extracted from in vitro putative pear transformants by the CTAB procedure of Doyle and Doyle(1990), as modified by Callahan et al. (1993). PCR for rolC was done as described by Scorza et al. (1994).

DNA blots were probed using the nonradioactive Genius digoxigenin (DIG) labeling and detection kit (Boehringer Manheim Corp., Indianapolis, Ind.). Ten micrograms of DNA of each GUS-positive pear clone were used for DNA blotting. EcoRI and HindIII digests were used to determine the integration of the rolC insert into the pear genome and the number of insertion events (Scorza et al., 1994). The DNA blots were also probed with the nptII gene probe, the primer sequence of which was kindly provided by J.L. Slightom, and as described by Fitch et al. (1992). The oligonucleotide primers for a 514-bp internal fragment of the rolC gene were described by Scorza et al. (1994). The rolC primers and nptII probes for DNA blotting were generated by PCR using DIG dUTP in the reaction mix as described by the manufacturer.

Total RNA was extracted from in vitro shoots using Purescript RNA isolation kit (Gentra System Inc., Minneapolis, Minn.) as modified for woody plant tissue (Robert Webb, USDA-ARS, Kearneysville, W.Va., personal communication). Fifty micrograms total RNA from each transgenic pear clone and untransformed controls were used for RNA blots. The RNA was separated in a 1.4\% formaldehyde agarose gel, transferred onto a Nytran membrane (Schleicher and Schuell, Keene, N.H.) by overnight capillary transfer using $20 \times$ SSPE ( 3 M sodium chloride, 0.2 m monobasic sodium phosphate, and $20 \mathrm{mmEDTA}$ ), and UV cross-linked. The rolCDNA fragment probe was generated using PCR, separated on 1.0\% agarose gel, and eluted with a Boehringer Manheim agarose gel DNA extraction kit. The probe was labeled with ${ }^{32}[\mathrm{P}] \mathrm{CTP}$ (NEN, Boston, Mass.) using RTS RadPrime DNA labeling system (BRL Life Technologies, Gaithersburg, Md.). After 2 h of prehybridization, the RNA blot was hybridized overnight at $42{ }^{\circ} \mathrm{C}$ with Hybrisol 1 solution (Oncor, Gaithersburg, Md.). After high stringency washing as suggested by the manufacturer, the blot was exposed to X-ray film with two intensifier screens at $-80^{\circ} \mathrm{C}$. In addition, the blot was exposed for two hours to a phosphor screen (Eastman Kodak Co., Rochester, N.Y.), and the phosphor image was scanned with a molecularimaging system (Storm 860; Molecular Dynamics, Sunnyvale, Calif.).

Extraction and immunoblotting of the rolC protein from in vitro grown transgenic pear clones were as described by Arora et al. (1992), with the following modifications. Total proteins were extracted by homogenizing in vitro rooted plantlets in the extraction buffer. After precipitating the proteins in $10 \%$ trichloroacetic acid at $0{ }^{\circ} \mathrm{C}$ for $30 \mathrm{~min}$, and centrifuging for $15 \mathrm{~min}$ at $15,000 \mathrm{~g}_{\mathrm{n}}$, the pellets were resuspended in $0.1 \% \mathrm{~L}$-methionine, $50 \mathrm{mmDTT}, 4 \% \mathrm{SDS}$, and $0.01 \%$ bromophenol blue. Samples of $100 \mu \mathrm{g}$ total protein were separated in $12 \%(\mathrm{w} / \mathrm{v})$ sodium dodecyl sulfate polyacrylamide Ready Gels (Bio-Rad, Hercules, Calif.), and electroblotted to an immobilon-P membrane (Millipore Corp., Danvers, Mass.).

Primary antibody was anti-rolC rabbit IgG that had been purified by affinity chromatography as described by Estruch et al. (1991). The final concentration was $4 \mu \mathrm{g} \cdot \mathrm{mL}^{-1}$. Secondary antibody was anti-rabbit goat IgG conjugated to alkaline phosphatase (Sigma Chemical Co., St. Louis, Mo.). The chromogenic substrate used was 5-bromo-4-chloro-3-indolyl phosphate/nitroblue tetrazolium(BCIP/ 


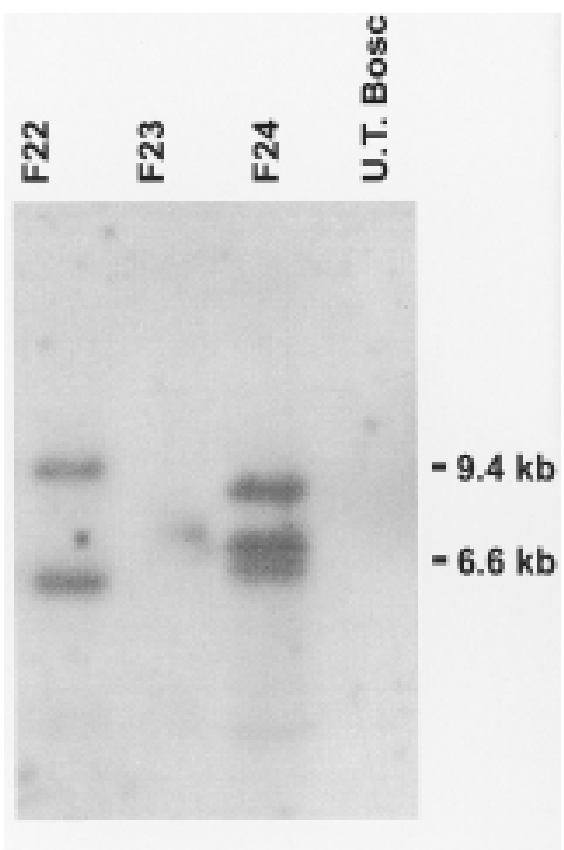

dipped in $500 \mathrm{mg} \cdot \mathrm{L}^{-1}$ IBA (dissolved in $1 \mathrm{~mL} 1 \mathrm{~N} \mathrm{KOH}$ and diluted with water to $\mathrm{pH} 6$ to 7 ) and planted in rooting medium containing $1 / 2 \mathrm{MS}$ salts, MS vitamins, $20 \mathrm{~g} \cdot \mathrm{L}^{-1}$ sucrose and $6 \mathrm{~g} \cdot \mathrm{L}^{-1}$ agar, with $\mathrm{pH}$ adjusted to 5.6. Rooting cultures were incubated under light. Root initiation occurred within a week. After 2 to 3 weeks in the rooting medium, rooted plants were transfered to Magenta vessels containing an autoclaved potting mixture (4 perlite : 1 vermiculite), wetted with liquid MS salts and $5 \mathrm{~g} \cdot \mathrm{L}^{-1}$ RootShield (Bio Works, Inc., Geneva, N.Y.) to prevent root and collar rots. The plants were maintained under light at $24{ }^{\circ} \mathrm{C}$. Three to four weeks later, the vessels containing plants were transferred to the greenhouse, and the plants were sprayed with an aqueous solution $(1: 20 \mathrm{v} / \mathrm{v})$ of AntiStress 2000 (Polymer Ag, Fresno, Calif.). One or 2 weeks later, the plants were transfered to 3 -inch square peat pots containing the potting mix. Acclimatization of rooted plants in the greenhouse was achieved by covering the plants with inverted Magenta vessels and irrigating with MS salts containing Rootshield to prevent root and collar rots.

GrowTH CHARACTERISTICS OF TRANSGENIC PLANTS. Self-rooted plants of the transgenic clones, untransformed regenerants, and plants derived from shoot proliferation cultures were grown for $\approx 6$ months in the greenhouse, beginning October 1997. Natural daylight was supplemented with high pressure sodium lamps, with a photoperiod of $16 \mathrm{~h}$ light : $8 \mathrm{~h}$ dark. Total shoot length was measured in millimeters, and the number of nodes were counted in March 1998, and mean internode length per plant was computed by dividing shoot length by number of nodes. The data were subjected to an analysis of variance using SAS PROC GLM (SAS Institute, Cary, N.C.), with Type III sums of squares. Clone means were separated using the Waller-Duncan $\mathrm{K}$ ratio $t$ test $(\mathrm{K}$ ratio $=100)$.

Budded plants were produced on 'Bartlett' seedling rootstock 0.7 to $0.9 \mathrm{~cm}$ in diameter. Buds were excised from single self-rooted plants of F22 and F23 transgenic clones, and the shoot proliferation and regenerant controls after the plants had been growing in the greenhouse for 7 months. One week following budding, the rootstocks were cut 2 to $4 \mathrm{~cm}$ above the inserted buds, and the plants were placed at $4{ }^{\circ} \mathrm{C}$ in the dark for $70 \mathrm{~d}$ to meet the dormancy requirement for budbreak. In June 1998 the plants were moved to the greenhouse and grown at $28^{\circ} \mathrm{C}$ under natural daylength. After 3 and 6 weeks, shoot length and number of nodes on each plant were recorded. At
6 weeks, the leaf area of three leaves from the middle of each shoot was measured using a portable area meter (LI-3000; LI-COR, Lincoln, Nebr.). Clone means were separated using the WallerDuncan Kratio $t$ test $($ Kratio $=100)$. The variance in leaf area among plants within clones was considered a random effect, and, therefore, was used as the error term in $\mathrm{F}$ tests of differences among clones.

\section{Results and Discussion}

Transformation. Following incubation on kanamycin selection medium, eighteen regenerated shoots of 'Beurre Bosc' and three regenerated shoots of 'Bartlett' were obtained from the fresh explants cultures inoculated with the 0.1 OD suspension. Seven regenerated shoots of 'Beurre Bosc' were obtained from the explants inoculated with the 0.5 OD suspension. No regenerants were obtained from explants that had been wounded and precultured before inoculation. Although preculture of explants has improved transformation efficiency in other plant species, such as flax (McHughen et al., 1989), it did not appear to be beneficial for pear transformation. No regeneration was obtained from uninoculated control explants cultured on kanamycin selection medium.

Histochemical AND MOlecular assays. Positive GUS assays were obtained for two of the eighteen regenerated 'Beurre Bosc' plantlets inoculated with 0.1 OD inoculum and one of the seven 'Beurre Bosc' plantlets from the 0.5 OD inoculum. None of the three 'Bartlett' regenerants were GUS positive, suggesting that transformation had not occurred in this cultivar. Previous research has also shown that 'Bartlett' does not regenerate as easily as other pear cultivars (Leblay et al., 1991; R.L. Bell, unpublished data), which may explain the lack of GUS-positive 'Bartlett' transformants. Failure of integration of the GUS gene, as has been shown to occur in tobacco (Scorza et al., 1994), is another possible explanation.

PCR analysis detected the presence of the rolC gene in the three GUS-positive 'Beurre Bosc' clones (data not presented). DNA hybridization (Fig. 2) of the GUS-positive transgenic clones confirmed integration of the rolC gene into the 'Beurre Bosc' chromosomal DNA. DNA hybridization of the EcoRI digests indicated that the transgenic clone F23 had one copy of the rolC gene, while F22 had two copies, and F24 had three copies. The HindIII results

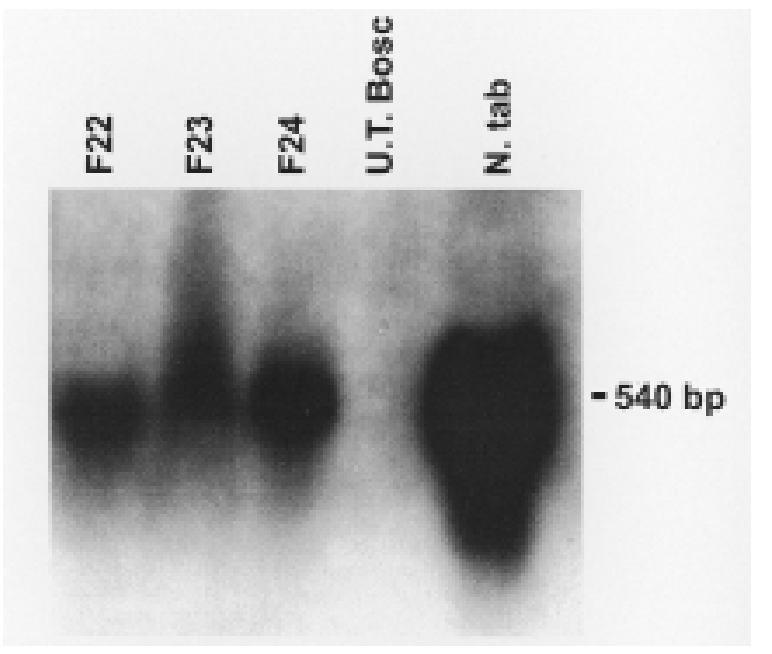

Fig. 3. RNA blot, probed with a 514-bp internal fragment of the rolC gene, of transgenic 'Beurre Bosc' pear clones F22, F23, and F24, plus an untransformed clone of 'Beurre Bosc' (UT Bosc) as a negative control and a transgenic clone of tobacco $(N . t a b)$ containing two copies of the rolC gene as a positive control. The rolC transcript is $\approx 540$ bp in length (Nilsson and Olsson, 1997; Slightom et al., 1986). 


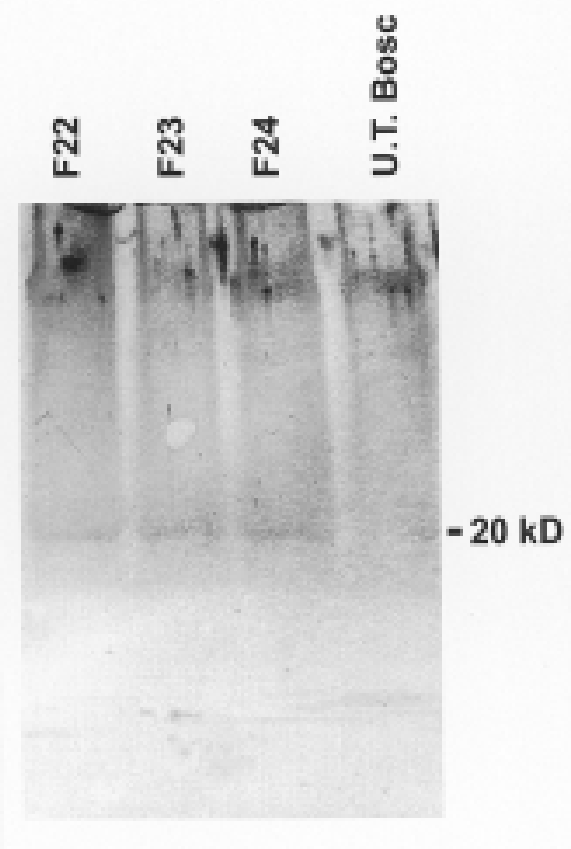

Fig. 4. Immunoblot of transgenic 'Beurre Bosc' pear clones F22, F23, and F24, showing expected bands at $20 \mathrm{kD}$, plus untransformed "Beurre Bosc' (UT Bosc) as a negative control.

provided confirmatory results (data not presented). The nptII probe produced results identical to those of the rolC probe (data not presented).

An overnight exposure of the RNA blots exhibited strong signals for all three transgenic clones and the transgenic tobacco control(Fig. 3). All signals were approximately equal to the predicted 540-bp transcript length (Nilsson and Olsson, 1997; Slightom et al., 1986). Immunoassay blots resulted in detectable $20 \mathrm{kD}$ bands for the three transgenic clones (Fig. 4), but no corresponding band in the untransformed control. Some nonspecific staining was observed, even in the untransformed 'Beurre Bosc' control.

GROWTH CHARACTERISTICS OF TRANSGENIC CLONES. Self-rooted plants of the untransformed regenerant and the proliferated shoots were significantly taller and had greater number of nodes than any

Table 1. Mean height, number of nodes, and internode length of 6-monthold self-rooted F22, F23, and F24 transgenic clones, untransformed regenerants, and plants derived from shoot proliferation cultures of 'Beurre Bosc' pear.

\begin{tabular}{lcccc}
\hline Clone & $\begin{array}{c}\text { Plants } \\
\text { (no.) }\end{array}$ & $\begin{array}{c}\mathrm{Ht} \\
(\mathrm{cm})\end{array}$ & $\begin{array}{c}\text { Nodes } \\
(\text { no. })\end{array}$ & $\begin{array}{c}\text { Internode } \\
\text { length } \\
(\mathrm{cm})\end{array}$ \\
\hline Proliferation & 10 & $36.0 \mathrm{a}^{\mathrm{z}}$ & $23.5 \mathrm{a}$ & $1.6 \mathrm{a}$ \\
Untransformed & 10 & $31.2 \mathrm{a}$ & $27.4 \mathrm{a}$ & $1.1 \mathrm{ab}$ \\
F24 & 10 & $9.9 \mathrm{~b}$ & $13.4 \mathrm{~b}$ & $0.8 \mathrm{~b}$ \\
F22 & 10 & $6.1 \mathrm{~b}$ & $6.3 \mathrm{c}$ & $1.1 \mathrm{ab}$ \\
F23 & 5 & $3.8 \mathrm{~b}$ & $5.9 \mathrm{c}$ & $0.8 \mathrm{~b}$
\end{tabular}

${ }_{\mathrm{z}}$ Mean separation among clones by Waller-Duncan $\mathrm{R}$ ratio $t$ test, $\mathrm{K}$ ratio $=$ 100. of the transgenic clones (Table 1). The F24 clone had a significantly greater number of nodes than F22 and F23. Mean internode length was greatest in plants derived from shoot proliferation cultures, but did not differ significantly from that of the untransformed regenerant and the F22 transgenic clones. While F23 and F24 differed significantly from the shoot proliferation clone, they did not differ significantly from F22 and the untransformed regenerant.

At both 3 and 6 weeks, plants of two transgenic clones budded onto 'Bartlett' seedling rootstock, F22 and F23, were significantly shorter than the untransformed shoot proliferation and regenerated controls, and did not differ significantly from each other either in height, number of nodes, or internode length (Table 2). The F23 transgenic clone was not statistically different from the untransformed regenerant clones at 3 weeks for internode length, and at 6 weeks for number of nodes, but had significantly fewer nodes at 3 weeks, and significantly shorter internodes at 6 weeks. The F22 clone was shorter in total height, had fewer nodes, and shorter internode lengths than the controls on both measurement dates. At 6 weeks, the mean leaf areas of the transgenic clones were significantly smaller than those of the proliferation and untransformed controls, while not significantly different from each other. The untransformed regenerant clones were significantly shorter than the shoot proliferation clones, had shorter internodes, and smaller leaf areas at both 3 and 6 weeks, and fewer nodes at 6 weeks. Although F22, with 2 copies of the rolC gene, exhibited reductions in all growth characteristics in comparison with F23, with a single copy of the gene, we cannot conclude on the basis of two clones that copy number affects phenotypic expression. Holefors et al. (1998), working with transgenic M26 apple rootstock, were not able to correlate similar alterations in plant phenotype with copy number of the rolA gene from A. rhizogenes.

\section{Conclusions}

Putative transformants of 'Beurre Bosc' and 'Bartlett' pear were selected on the basis of regeneration on kanamycin selection medium. Transgenic status of a total of three clones of 'Beurre Bosc' pear has been confirmed by positive GUS histochemical assays, and by genomic DNA blots, which indicated from 1 to 3 copies of the rolC gene had been integrated in each clone. Further confirmation of rolC gene expression has been provided by RNA hybridization blots and immunoassays.

The young self-rooted and budded plants of the rolC transformants exhibited readily discernible reductions in total height, number of nodes, and leaf area, and in internode length of the budded plants. This report documents the first successful transformation of pear with a gene of potential economic significance. The natural growth habit of 'Beurre Bosc' is characterized by extensive yearly shoot growth and would benefit from a reduction in vigor as long as

Table 2. Mean height, number of nodes, internode length, and leaf $\operatorname{area}^{\mathrm{z}}$ of budded plants of two rolC transformed pear clones, F22 and F23, and untransformed regenerants, and plants derived from shoot proliferation cultures of 'Beurre Bosc' pear.

\begin{tabular}{|c|c|c|c|c|c|c|c|c|}
\hline \multirow[b]{2}{*}{ Clone } & \multicolumn{4}{|c|}{3 weeks } & \multicolumn{4}{|c|}{6 weeks } \\
\hline & $\begin{array}{c}\text { Plants } \\
\text { (no.) }\end{array}$ & $\begin{array}{l}\mathrm{Ht} \\
(\mathrm{cm})\end{array}$ & $\begin{array}{l}\text { Nodes } \\
\text { (no.) }\end{array}$ & $\begin{array}{c}\text { Internode } \\
\text { length }(\mathrm{cm})\end{array}$ & $\begin{array}{l}\mathrm{Ht} \\
(\mathrm{cm})\end{array}$ & $\begin{array}{l}\text { Nodes } \\
\text { (no.) }\end{array}$ & $\begin{array}{c}\text { Internode } \\
\text { length }(\mathrm{cm})\end{array}$ & $\begin{array}{l}\text { Leaf area } \\
\left(\mathrm{cm}^{2}\right)\end{array}$ \\
\hline Proliferation & 8 & $167.4 \mathrm{a}^{\mathrm{y}}$ & $15.9 \mathrm{a}$ & $10.5 \mathrm{a}$ & $381.3 \mathrm{a}$ & $33.6 \mathrm{a}$ & $11.2 \mathrm{a}$ & $6.6 \mathrm{a}$ \\
\hline Untransformed & 3 & $109.7 \mathrm{~b}$ & $15.7 \mathrm{a}$ & $6.9 \mathrm{~b}$ & $246.7 \mathrm{~b}$ & $26.0 \mathrm{~b}$ & $9.0 \mathrm{~b}$ & $4.7 \mathrm{~b}$ \\
\hline $\mathrm{F} 23$ & 11 & $64.9 \mathrm{c}$ & $11.5 \mathrm{~b}$ & $5.3 \mathrm{bc}$ & $72.7 \mathrm{c}$ & $21.9 \mathrm{bc}$ & $3.1 \mathrm{c}$ & $2.7 \mathrm{c}$ \\
\hline $\mathrm{F} 22$ & $14(12)^{x}$ & $38.8 \mathrm{c}$ & $9.8 \mathrm{~b}$ & $3.5 \mathrm{c}$ & $53.8 \mathrm{c}$ & $17.4 \mathrm{c}$ & $2.9 \mathrm{c}$ & $2.4 \mathrm{c}$ \\
\hline
\end{tabular}

${ }^{\mathrm{z}}$ Mean of three leaves per plant.

'Mean separation among clones by Waller-Duncan $\mathrm{R}$ ratio $t$ test, $\mathrm{K}$ ratio $=100$.

${ }^{\mathrm{x}}$ At 6 weeks, only 12 plants were analyzed, due to broken grafts. 
productivity is not adversely affected. Guivarc'h et al. (1996), using immunolocalization, found that the expression of the rolC gene in transgenic tobacco was restricted to companion cells of the phloem strands, and to the initials of root protophloem cells. Their studies also indicated a physical separation between the sites of expression and actions of the rolC gene in transgenic plants, with meristem, pith, and leaf parenchyma cells affected by rolC expression, presumably through an alteration in hormonal balance. Their findings suggest that it is possible that rolC transgenic pears used as rootstocks may have growth-altering effects on scions. The transgenic clones will continue to be evaluated for differences in growth habit to assess the potential of $\mathrm{rol} C$ for producing beneficial alterations in growth and development in pear scion and rootstock cultivars.

\section{Literature Cited}

Arora, R., M.E. Wisniewski, and R. Scorza. 1992. Cold acclimation in genetically related (sibling) deciduous and evergreen peach [Prunus persica (L.) Batsch]. I. Seasonal changes in cold hardiness and polypeptides of bark and xylem tissues. Plant Physiol. 99:1562-1568.

Callahan, A.M., P.H. Morgens, and R.A. Cohen. 1993. Isolation and initial characterization of cDNAs for mRNAs regulated during peach fruit development. J. Amer. Soc. Hort. Sci. 118:531-537.

Chevreau, E., and C. Leblay. 1993. The effect of mother plant pretreatment and explant choice on regeneration from in vitro pear leaves. Acta Hort. 336:263-268.

Doyle, J.J. and J.L. Doyle. 1990. Isolation of plant DNA from fresh tissue. BRL Focus 12:13-15.

Estruch, J.J., A. Parets-Soler, T. Schmulling, and A. Spena. 1991. Cytosolic localization in transgenic plants of the rolC peptide from Agrobacterium rhizogenes. Plant Mol. Biol. 17:547-550.

Fitch, M.M.M., R.M. Manshardt, D. Gonsalvez, J.L. Slightom, and J.C. Sanford. 1992. Virus resistant papaya plants derived from tissues bombarded with the coat protein gene of papaya ringspot virus. BioTechnology 10:1466-1472.

Fladung, M. 1990. Transformation of diploid and tetraploid potato clones with the rolC gene of Agrobacterium rhizogenes and the characterization of transgenic plants. Plant Breeding 104:295-304.

Guivarc'h, A., A. Spena, M. Noin, C. Besnard, and D. Chriqui. 1996. The pleiotropic effects induced by the rolC gene in transgenic plants are caused by expression restricted to protophloem and companion cells. Transgenic Res. 5:3-11.

Holefors, A., Z.T. Xue, and M. Welander. 1998. Transformation of apple rootstock M26 with the rolA gene and its influence on growth. Plant Sci. 136:69-78.

James, D.J., S. Uratsu, J. Cheng, P. Negri, P. Viss, and A.M. Dandekar. 1993. Acetosyringone and osmoprotectants like betaine or proline synergistically enhance Agrobacterium-mediated transformation of apple. Plant Cell Rpt. 12:559-563.

Jefferson, R.A. 1987. Assaying chimeric genes in plants: The GUS gene fusion system. Plant Mol. Biol. Rpt. 5:387-405.
Leblay, C., E. Chevreau, and L.M. Raboin. 1991. Adventitious shoot regeneration from in vitro leaves of several pear cultivars (Pyrus communis L.) Plant Cell Tiss. Org. Cult. 16:75-87.

Lombard, P.B. and M.N. Westwood. 1987. Pear rootstocks, p. 145-183. In: R.C. Rom and R.F. Carlson (eds.). Rootstocks for fruit crops. Wiley, New York.

McHughen, A., M. Jordan, and G. Feist. 1989. A preculture period prior to Agrobacterium inoculation increases production of transgenic plants. J. Plant Physiol. 135:245-248.

Merkulov, S.M.,I.V.Bartish,S.V.Dolgov, T.P.Pasternak, and A.McHugen. 1998. The genetic transformation of the pear Pyrus communis L. mediated by Agrobacterium tumefaciens. Russian J. Genet. 34:289-293.

Mourgues. F., E. Chevreau, C. Lambert, and A. de Bondt. 1996. Efficient Agrobacterium-mediated transformation and recovery of transgenic plants from pear (Pyrus communis L.) Plant Cell Rpt. 16:245-249.

Murashige, T. and F. Skoog. 1962. A revised medium for rapid growth and bioassays with tobacco tissue cultures. Physiol. Plant. 15:473-497.

Nilsson, O., T. Moritz, N Imbault, G. Sandberg, and O. Olsson. 1993. Hormonal characterization of transgenic tobacco plants expressing the rolC gene of Agrobacterium rhizogenes $\mathrm{T}_{\mathrm{L}}$-DNA. Plant Physiol. 102:363371.

Nilsson, O., T. Moritz, B. Sundberg, G. Sandberg, and O. Olsson. 1996. Expression of the Agrobacterium rhizogenes rolC gene in a deciduous forest tree alters growth and development and leads to stem fasciation. Plant Physiol. 112:493-502.

Nilsson, O. and O. Olsson. 1997. Getting to the root: the role of the Agrobacterium rhizogenes rol genes in the formation of hairy roots. Physiol. Plant. 100:463-473.

Nilsson, O., H. Tuominen, B. Sundberg, and O. Olsson. 1997. The Agrobacterium rhizogenes rolB and rolC promoters are expressed in pericycle cells competent to serve as root initials in transgenic aspen. Physiol. Plant. 100:456-462.

Rom, R.C. and R.F. Carlson. 1987. Rootstocks for fruit crops. Wiley, New York.

Schmulling, T., J. Schell, and A. Spena. 1988. Single genes from Agrobacterium rhizogenes influence plant development. EMBO 7:2621-2629.

Scorza, R., T.W. Zimmerman, J.M. Cordts, K.J. Footen, and M. Ravelonandro. 1994. Horticultural characteristics of transgenic tobacco expressing the rolC gene from Agrobacterium rhizogenes. J. Amer. Soc. Hort. Sci. 119:1091-1098.

Slightom, J.L., M. Durand-Tardif, L. Jouanin, and D. Tepfer. 1986. Nucleotide sequence analysis of the TL-DNA of Agrobacterium rhizogenes agropine type plasmid. J. Biol. Chem. 261:108-121.

Tukey, H.B. 1964. Dwarfed fruit trees. Macmillan, New York.

van Altvorst, A.C., R.J. Bino, A.J. van Dijk, A.M. J. Lamers, W.H. Lindhout, F. van der Mark, and J.J. M. Dons. 1992. Effects of the introduction of Agrobacterium rhizogenes rol genes on tomato plant and flower development. Plant Sci. 83:77-85.

van der Salm, T.P.M., C.J.G. van der Toorn, Ch. H. Hanisch ten Cate, L.A.M. Dubois, D.P. de Vries, and J.J.M. Dons. 1992 Introduction of rol genes in rootstocks of rose. Physiol. Plant. 85:A7 abstr. 42. 